JKKP: Jurnal Kesejahteraan Keluarga dan Pendidikan

http://doi.org/10.21009/JKKP

DOI: doi.org/10.21009/JKKP.031.06

E-ISSN: 2597-4521

\title{
PENGARUH PERAN TEMAN SEBAYA TERHADAP TINGKAT KENAKALAN REMAJ A DI LAPAS ANAK WANITA KELAS II B TANGERANG
}

\author{
Zuvin Natul Ummah 1), Sitti Nursetiawati 2), Vera Utami Gede Putri ${ }^{3)}$ \\ 1)P rogram Studi Pendidikan Kesejahteraan Keluarga \\ 2) Program Studi Pendidikan Tata Rias \\ 3)Program Studi Pendidikan Busana \\ Fakultas Teknik, Universitas Negeri J akarta \\ J In. Rawamangun Muka, J akarta Timur 13220
}

\begin{abstract}
Abstrak
Masa remaja merupakan masa yang sangat rentan terhadap perilaku yang salah karena pengaruh negatif lingkungan sosial dan kurang pengawasan dari orang tua. Pada masa remaja komunikasi dan kepercayaan terhadap orang tua berkurang, dan beralih kepada teman sebaya untuk memenuhi kebutuhan akan kelekatan (attachment). Lingkungan teman sebaya yang negatif dapat mendorong terlibat dalam kenakalan remaja. Penelitian ini bertujuan untuk mengetahui pengaruh teman sebaya terhadap tingkat kenakalan remaja di Lapas Anak Wanita kelas IIB Tangerang. Populasi penelitian ini adalah warga binaan di Lapas Anak Wanita Tangerang yang berusia 17 hingga 21 tahun yang berjumlah 75 remaja. Teknik yang digunakan adalah teknik sampling jenuh. Berdasarkan penelitian yang telah dilakukan, diketahui nilai koefisien korelasi $r x y=0.235$ dan thitung $(2.00)>$ ttabel $(1,99)$. Sehingga dapat disimpulkan bahwa terdapat pengaruh positif yang signifikan antara pergaulan teman sebaya terhadap tingkat kenakalan remaja. Pergaulan teman sebaya memiliki sumbangan sebesar 5,52\% terhadap tingkat kenakalan remaja, sehingga semakin tinggi pergaulan teman sebaya maka semakin tinggi pula tingkat kenakalan remaja.
\end{abstract}

Kata kunci : Teman sebaya, kenakalan, remaja wanita, narapidan

\section{The Influence Of Peers Aginst The Level Of Adolescent Mischief In Class IIB Women's Prison Children Tangerang}

\begin{abstract}
Adolescence is a period that is very susceptible to incorrect behavior because of the negative influence of the social environment and less supervision from parents. In adolescence, communication and confidence to parents is reduced, and switch to the peers to fill the needs for attachment. Negative peers environment can encourage involved in adolescent mischief. This study aims to determine the influence of peers on the level of adolescent mischief in class IIB Women's Prison Children Tangerang. he study population was of inmates in prisons Anak Tangerang Women aged 17 to 21 years as many as 75 adolescents. The technique used is saturated sampling technique. Based on research, it is known the correlation coefficient rxy $=0.235$ and tcount $(2.00)>t$ table(1.99). So it can be concluded that there is a significant positive influence among social peers against the level of adolescent mischief. R elationship of peers have a contribution of $5.52 \%$ against the level of adolescent mischief, so the higher relationship of peers, the higher the rate of adolescent mischief.
\end{abstract}

Keyword : Peers, mischief, women, adolescent, prison

\section{PENDAHULUAN}

Remaja adalah masa di mana seorang individu mengalami peralihan dari masa anak-anak menuju dewasa. Masa remaja memang masa yang menyenangkan sekaligus masa yang tersulit 
dalam hidup seseorang. Sebelum dewasa individu akan mengalami masa dimana terjadi peralihan untuk benar-benar mematangkan dirinya menuju masa dewasa. Pada masa ini sebagian besar remaja mengalami gejolak dimana terjadi perubahan pada dirinya baik secara fisik, psikis, maupun secara sosial (Sudarsono, 2004). Oleh karena itu masa remaja di sebut-sebut masa yang paling rawan dihadapi individu sebagai anak. Dari yang tadinya anak-anak mereka mengalami perkembangan secara fisik maupun psikis dengan beberapa perubahan.

Di masa ini seorang anak mulai mencari jati diri. Pada masa peralihan, status remaja tidaklah jelas dan terdapat keraguan akan peran yang harus dilakukan. Di satu sisi, remaja bukan lagi seorang anak dan disisi lain bukan pula orang dewasa. Kebanyakan orang dewasa masih menganggap mereka mereka sebagai anak-anak. Usia krisis remaja pada wanita berkisar antara 15,5 - 16,5 tahun, sedangkan pada laki-laki berkisar antara 16-17 tahun (Sudarsono 2004). Remaja belum sanggup berperan sebagai orang dewasa, tetapi tidak mau disebut bahwa dia masih anakanak. Karena orang dewasa enggan memberikan peranan dan tanggung jawab kepada mereka, maka hal itu dirasakan oleh remaja sebagai kurangnya penghargaan. Perasaan kurang dihargai itu muncul dalam kelainan-kelainan tingkah laku remaja seperti kebut-kebutan di jalan raya, menghisap ganja, berkelahi dan sebagainya. Semua contoh kenakalan tersebut merupakan penyimpangan perilaku yang menyebabkan ketidaktentraman pada diri sendiri maupun orang lain. Remaja ingin menyatakan wujud kedewasaannya, ingin menyatakan identitas dirinya dan ingin pula membuktikannya. Akan tetapi terkadang remaja menghadapi hambatan-hambatan, apalagi yang sifatnya berlawanan dengan jiwa mudanya, yang bertentangan dengan hati kecilnya, yang bertentangan dengan selera, gaya hidup, dan tujuannya. Apabila keinginannya terus berlanjut, karena orangtua tidak mau mengerti, remaja akan memberontak.

BNN melaporkan pada tahun 2010, prevalensi penyalahgunaan narkoba meningkat menjadi 2,21\% atau sekitar 4,02 juta orang. Pada tahun 2011, prevalensi penyalahgunaan meningkat menjadi 2,8 persen atau sekitar 5 juta orang (Kompas.com, 26 Juni 2011). Seperti yang diberitakan oleh Majalah Wanita Kartini, 14 Juni 2012, hasil survei Komisi Perlindungan Anak Indonesia (KPAl) terhadap 4.500 remaja di 12 kota besar menghasilkan 93,7\% pernah berciuman, petting dan oral, $62 \%$ remaja di Indonesia pernah berhubungan intim. Fakta lainnya yang juga mencengangkan, sekitar $21,2 \%$ remaja putri di Indonesia pernah melakukan aborsi. Survei juga menyebutkan, $97 \%$ perilaku seks remaja diilhami pornografi di internet. Berdasarkan penelitian tahun 2010/2011 di Jakarta, Tangerang, dan Bekasi dengan jumlah sampel 3006 responden dengan usia 17-24 tahun, hasil menunjukkan $20.9 \%$ remaja mengalami kehamilan dan kelahiran sebelum menikah.

Berdasarkan fenomena kenakalan remaja yang terjadi di kota besar Indonesia, serta faktor yang mempengaruhi kenakalan remaja, maka peneliti merasa tertarik untuk mengangkat topik kenakalan remaja sebagai bahan penelitian. Khususnya pada remaja wanita yang telah menjadi penghuni lapas akibat tindak kejahatan yang dilakukannya, seorang wanita yang seharusnya mempunyai sifat lemah lembut, keibuan, sensitivitas yang tinggi justru pada kenyataannya banyak yang melakukan tindak kriminal, apakah faktor yang memicu mereka untuk melakukan tindak kejahatan tersebut.

Peneliti ingin mengetahui Apakah Ada Pengaruh Teman Sebaya Terhadap Tingkat Kenakalan Remaja. Adapun kelompok teman sebaya yang dimaksud dalam penelitian ini adalah kelompok teman sebaya yang mengarah pada hal negatif.

\section{METODOLOGI PENELITIAN}

Populasi sasaran dalam penelitian ini adalah warga binaan di Lapas Anak Wanita Tangerang yang berusia 17 hingga 21 tahun yang digolongkan termasuk remaja usia sekolah SMP, SMA, dan Perguruan Tinggi. Adapun jumlah keseluruhan populasi tersebut berjumlah 75 remaja. Alasan dipilihnya populasi seluruh remaja usia sekolah SMP, SMA, dan Perguruan Tinggi dikarenakan Tingkat Kenakalan Remaja pada usia akhir ini sangat tinggi. 
Teknik yang digunakan dalam menentukan sampel penelitian ini adalah teknik sampling jenuh yang mana semua anggota populasi digunakan sebagai sampel. Teknik sampling jenuh adalah teknik penentuan sampel bila semua anggota populasi digunakan sebagai sample (Sugiyono, 2010: 85).

\section{HASIL DAN PEMBAHASAN}

Berdasarkan penelitian yang telah dilakukan, diketahui nilai koefisien korelasi $r x y=0.235$ dan thitung $(2.00)>$ ttabel $(1,99)$, Sehingga dapat disimpulkan bahwa terdapat pengaruh positif yang signifikan antara pergaulan teman sebaya terhadap tingkat kenakalan remaja. Pergaulan teman sebaya memiliki sumbangan sebesar $5,52 \%$ terhadap tingkat kenakalan remaja, sehingg semakin tinggi pergaulan teman sebaya maka semakin tinggi pula tingkat kenakalan remaja. Demikian sebaliknya semakin rendah pergaulan teman sebaya maka semakin rendah pula tingkat kenakalan remaja.

Namun pergaulan teman sebaya yang dimaksudkan dalam penelitian ini adalah pergaulan yang mengarah pada hal-hal negatif, tetapi jika remaja bergaul dengan teman sebaya yang mengarahkan pada nilai positif tentu kenakalan remaja akan semakin berkurang, dan manfaat yang di dapatkan akan semakin banyak seiring dengan banyaknya teman sebaya yang di miliki.

Bila dilihat dari total keseluruhan variabel pergaulan teman sebaya dan variabel tingkat kenakalan remaja, di mana pergaulan teman sebaya mempunyai 3 aspek (Sumber Informasi, sumber kognitif, sumber emosional). Sedangkan tingkat kenakalan remaja mempunyai 1 aspek yaitu bentuk kenakalan remaja yang terdiri dari 4 indikator (Kenakalan yang menimbulkan korban fisik pada orang lain, kenakalan yang menimbulkan korban materi, kenakalan sosial yang tidak menimbulkan korban di pihak orang lain, dan kenakalan yang melawan status sosial).

Variabel ini memiliki 3 dimensi. Dimensi tertinggi pada variabel pergaulan teman sebaya yaitu sumber informasi mengenai dunia diluar keluarga dengan dua indikator yaitu; jumlah teman, dan interaksi pergaulan dengan teman. Pada indikator pertama yaitu jumlah teman mendapat skor sebesar 270,6 dengan presentase sebesar $19,96 \%$, hal ini disebabkan karena remaja di lapas anak wanita Tangerang memiliki jumlah teman yang cukup banyak, sehingga terjadi interaksi yang cukup Luas pada pergaulan dengan temannya. Pada indikator kedua yaitu interaksi pergaulan dengan teman ini mendapat skor sebesar 279,33 dengan presentase sebesar 279,33.

\section{Peran Teman Sebaya}

Variabel ini memiliki 3 dimensi. Dimensi tertinggi pada variabel pergaulan teman sebaya yaitu sumber informasi mengenai dunia diluar keluarga dengan dua indikator yaitu; jumlah teman, dan interaksi pergaulan dengan teman. Pada indikator pertama yaitu jumlah teman mendapat skor sebesar 270,6 dengan presentase sebesar 19,96\%, hal ini disebabkan karena remaja di lapas anak wanita Tangerang memiliki jumlah teman yang cukup banyak, sehingga terjadi interaksi yang cukup luas pada pergaulan dengan temannya. Pada indikator kedua yaitu interaksi pergaulan dengan teman ini mendapat skor sebesar 279,33 dengan presentase sebesar 279,33.

Untuk dimensi terendah pada variable pergaulan teman sebaya yaitu sumber kognitif mendapat skor sebesar 272 dengan presentase sebesar 20,09\% yang terdapat pada butir soal nomor 38, yang berbunyi "saya menganggap pendapat teman tidak bermanfaat bagi kepentingan kelompok". Hal ini disebabkan karena remaja di Lapas Anak Wanita Tangerang sudah memiliki kesadaran untuk saling menghargai pendapat temannya di dalam kelompok, di dalam Lapas mereka menemukan hal-hal baru dari teman yang memiliki nasib yang sama, sebagian dari mereka prihatin dengan keadaan yang mereka alami di dalam Lapas, mereka mulai belajar dan berubah untuk saling mendengarkan, menceritakan pengalaman masing-masing oleh karena itu mereka menganggap pendapat teman dibutuhkan dalam sebuah kelompok. Dengan begitu hasil rendah dari dimensi sumber kognitif menunjukkan hal yang positif bagi pergaulan teman sebaya. 


\section{Tingkat Kenakalan Remaja}

Variabel ini memiliki 1 dimensi dengan 4 indikator, indikator tertinggi pada variabel tingkat kenakalan remaja yaitu kenakalan yang menimbulkan korban fisik pada orang lain dengan skor sebesar 218,2 dengan presentase sebesar $25,55 \%$ yang terdapat pada soal nomor 2 yang berbunyi "saya suka berkelahi dengan orang yang membuat saya kesal", hal ini disebabkan karena banyak remaja di Lapas Anak Wanita Tangerang yang memiliki agresifitas yang tinggi sehingga jika ada orang yang membuatnya kesal tidak lagi berfikir panjang, untuk diajak berkelahi.

Hubungan yang tidak baik dengan keluarganya juga menjadi penyebab mereka memiliki sifat tempramental, kebanyakan dari mereka dibesarkan oleh keluarga yang buruk, keluarga yang tercerai berai, oleh karena itu mereka sering berkelahi dengan orang-orang yang membuatnya kesal, mereka tidak merasakan kenyamanan dengan orang-orang yang membuat emosinya meluap-luap oleh karena itu jawaban dari pernyataan tersebut memperoleh skor yang tinggi.

Tingginya skor butir 2, karena mayoritas tindak kejahatan yang dilakukan remaja di Lapas Anak Wanita Tangerang berasal dari keluarga yang berantakan dan penuh konflik, sehingga mereka mencari tempat yang bersedia menerima mereka dengan baik diluar lingkungan keluarga, dan biasanya lingkungan ini dapat mendorong amak untuk bertingkah laku negatif yang mengarah pada perilaku delinkuen.

Untuk indikator terendah pada variabel tingkat kenakalan remaja yaitu kenakalan sosial yang tidak menimbulkan korban dipihak orang lain dengan skor sebesar 204,38 dengan presentase $23,93 \%$ yang terdapat pada soal butir 35 yang berbunyi "saya pernah melakukan permainan judi bola di internet" hal ini disebabkan remaja-remaja di Lapas Anak Wanita Tangerang hanya sedikit yang melakukan kenakalan sosial yang tidak menimbulkan korban dipihak orang lain seperti; menjual diri, pergi dari rumah, membolos sekolah, dan memprovokasi teman. Karena di dalam Lapas ini sebagaian besar warga binaannya melakukan tindak kekerasan fisik.

\section{Hubungan Variabel $X$ dengan Variabel $Y$}

Berdasarkan hasil perhitungan product moment yang telah dilakukan diperolah koefisiensi korelasi antara pergaulan teman sebaya dengan tingkat kenakalan remaja adalah rhitung 0,235. Hasil penelitian tersebut menunjukkan hasil yang positif, yang berarti pergaulan teman sebaya berpengaruh positif terhadap tingkat kenakalan remaja. Dalam pergaulan remaja, kebutuhan untuk dapat diterima bagi setiap individu merupakan suatu hal yang sangat mutlak sebagai makhluk sosial. Setiap anak yang memasuki usia remaja akan dihadapkan pada permasalahan penyesuaian sosial, yang diantaranya adalah problematika pergaulan teman sebaya. Pembentukan sikap, tingkah laku dan perilaku sosial remaja banyak ditentukan oleh pengaruh lingkungan ataupun teman-teman sebaya.

Apabila lingkungan sosial itu memfasilitasi atau memberikan peluang terhadap remaja secara positif, maka remaja akan mencapai perkembangan sosial secara matang. Apabila lingkungan sosial memberikan peluang secara negatif terhadap remaja, maka perkembangan sosial remaja akan terhambat (Iriawati, 2002).

Pergaulan teman sebaya yang dilakukan para remaja berkaitan dengan tingkat kenakalan remaja, semakin tinggi pergaulan teman sebaya maka semakin tinggi pula tingkat kenakalan remaja. Pergaulan teman sebaya yang dimaksud adalah yang mengarah ke arah negatif, karena banyak pengaruh-pengaruh yang didapatkan ketika bergaul dengan teman, jika teman sebayanya mengarahkan pada hal-hal positif maka banyak pengaruh positif yang didapatkan dan juga sebaliknya jika teman sebayanya mengarahkan pada hal-hal negatif maka banyak pula pengaruh negatif yang didapatkan. Hasil penelitian dan perhitungan skor menunjukan rata-rata remaja pada lapas anak wanita memiliki pergaulan yang luas dan memiliki jumlah teman yang banyak, berdampingan dengan hasil skor tingkat kenakalan remaja yang juga tinggi. 
Hal tersebut menandakan bahwa pengaruh pergaulan teman sebaya dengan tingkat kenakalan remaja di Lapas Anak Wanita Tangerang saling berpengaruh positif tetapi tidak besar. Kekurangan dan kendala dalam penelitian juga mempengaruhi hasil, dimana keterbatasan waktu yang diberikan saat mengisi kuesioner sangat singkat, sehingga para remaja terburu-buru dalam mengisi jawaban. Sehingga sampel yang diperoleh belum cukup mewakili jawaban tentang tingkat kenakalan remaja

\section{KESIMPULAN DAN SARAN}

Berdasarkan pengolahan deskriptif, analisis, dan pengolahan data statistik maka dapat disimpulkan bahwa:

a. Pada variabel $x$ yaitu pergaulan teman sebaya pada remaja di Lapas Anak Wanita Tangerang memiliki tiga dimensi yaitu; sumber informasi mengenai dunia di luar keluarga, sumber kognitif, dan sumber emosional. Pada sumber dunia luar, terdapat indikator jumlah teman mendapat presentase sebesar $19,96 \%$ dan indikator interaksi pergaulan dengan teman sebaya mendapat presentase sebesar $20,60 \%$. Dimensi sumber kognitif memiliki indikator pemecahan masalah sebesar $20,09 \%$. Pada dimensi sumber emosional terdapat indikator saling bertukar pikiran mendapat presentase sebesar $19,64 \%$ dan indikator dorongan teman sebaya mendapat presentase sebesar $19,69 \%$.

b. Pada variabel y yaitu tingkat kenakalan remaja di Lapas Anak Wanita Tangerang yakni memiliki satu dimensi yaitu bentuk kenakalan remaja dengan empat indikator yaitu; kenakalan yang menimbulkan korban fisik pada orang lain sebesar $25.55 \%$, kenakalan yang menimbulkan korban materi $25,45 \%$, kenakalan sosial yang tidak menimbulkan korban dipihak orang lain $23,93 \%$, dan kenakalan yang melawan status sosial $25,05 \%$.

Terdapat pengaruh yang signifikan antara pergaulan teman sebaya terhadap tingkat kenakalan remaja di Lapas Anak Wanita Tangerang. Semakin tinggi pergaulan teman sebaya maka semakin tinggi pula tingkat kenakalan remaja. Pergaulan yang dimaksud dalam penelitian ini adalah pergaulan yang mengarah pada hal-hal negatif. Hasil perhitungan uji analisis statistik menyatakan bahwa $5,52 \%$ tingkat kenakalan remaja ditentukan oleh pergaulan teman sebaya, sedangkan sisanya $94,48 \%$ ditentukan oleh variabel lain yang tidak diteliti.

\section{SARAN}

Berdasarkan hasil penelitian ini, maka disarankan:

1. Responden diharapkan dapat memikirkan kembali mengenai keputusan untuk bergaul, memilih teman dan lingkungan sekitar yang baik agar tidak salah dalam bergaul sehingga terhindar dari faktor resiko yang harus di tanggung dan dampak yang memberikan kerugian kepada diri sendiri.

2. Diperlukan adanya penyuluhan tentang pergaulan teman sebaya agar lingkungan memahami bahwa keterlibatannya dalam membentuk karakter remaja untuk mengurangi terjadi kenakalan remaja.

3. Diperlukan penelitian mendalam, mengenai kaitan pergaulan teman sebaya dan tingkat kenakalan remaja, dan meneliti tentang faktor-faktor lain yang dapat mempengaruhi tingkat kenakalan remaja

\section{DAFTAR PUSTAKA}

Irawati, D. 2002. Hubungan Antara Penerimaan Teman Sebaya dengan Kematangan Sosial pada Remaja. Skripsi. Fakultas Psikologi JIPTUMM. Bandung

Sudarsono.2004. Kenakalan Remaja. Penerbit Rineka Cipta. Jakarta.

Sugiyono. 2010. Metode Penelitian Kuantitatif, Kualitatif, \& RnD. Alfabeta. Bandung 